\title{
Efek Pemberian Decanter Solid terhadap Pertumbuhan Bibit Kelapa Sawit (Elaeis guineensis Jacq) dengan Media Tanah Bekas Lahan Tambang Batu Bara di Pembibitan Utama
}

\author{
Anis Tatik Maryani* \\ Program Studi Agroekoteknologi, Fakultas Pertanian, Universitas Jambi \\ *Corresponding author: anis_tatik@yahoo.com
}

\begin{abstract}
Land resource hoarding coal post is supporting agricultural development. Experiment on the use of the media to land former coal mines that are expected to become soil ameliorant media or media after seedlings seeds moved into the field. The purpose of this study is 1) Determining the growth of oil palm seedlings with soil medium former coal mining areas. 2) Determining the decanter solid dose of the best on the growth of oil palm seedlings on former pasture land of coal mines in the main nursery. Design of experiment was randomized block design (RBD) with 7 dose treatment levels of decanter solid, there is no decanter solid, 100, 200, 300, 400, 500, and $600 \mathrm{~g} /$ polybag. Each treatment was replicated four times, so there are 28 experimental units. Each experimental unit consisted of three plants and as an each of them as plant sample, thus totally there are 84 plants. Observed variables include the increase of plant height, plant diameter $(\mathrm{cm})$ and leaf area $\left(\mathrm{cm}^{2}\right)$ as well as the rate of plant growth and Seed Quality Index. Results of the research show that in general the administration of decanter solid on the growth of seedlings of oil palm with former land area coal mines provide better growth on the plant height, diameter, number of leaves, leaf area, increase the rate of plant growth as well as seed quality index compared to oil palm seedlings without any decanter solid. Decanter solid 400 g/polybag is the best for the growth of oil palm seedlings.
\end{abstract}

Keywords: Decanter solid; Oil palm seed; Land former coal mine land; Main nursery

Cite this as: Maryani, A.T. 2018. Efek Pemberian Decanter Solid terhadap Pertumbuhan Bibit Kelapa Sawit (Elaeis guineensis Jacq) dengan Media Tanah Bekas Lahan Tambang Batu Bara di Pembibitan Utama. Caraka Tani: Journal of Sustainable Agriculture. 33(1), 50-56. doi:http://dx.doi.org/10.20961/carakatani.v33i1.19310

\section{PENDAHULUAN}

Kegiatan penambangan dan hasil reklamasi lahan pasca penambangan pada akhirnya harus memenuhi indikator ramah lingkungan sehingga lahan pasca penambangan tersebut benar-benar dapat bermanfaat bagi kehidupan masyarakat sekitar, Luas lahan Pertambangan di Provinsi Jambi pada tahun 2014 seluas 387.344,50 ha (Lubis, 2014). Menurut Kumar (2013) kegiatan penambangan dapat mengubah sifat fisik dan kimia serta lingkungan biologis tanah. Keadaan ini ditandai oleh kandungan bahan organik rendah, $\mathrm{pH}$ rendah bahkan sangat rendah, kapasitas memegang air rendah (low water holding capacity) rendah, salinitas, tekstur kasar, pemadatan tanah, pasokan unsur hara pada tanaman tidak memadai, erosi dipercepat, dan bahan pembangkit asam. Pribadi (2012) menyatakan bahwa perubahan kimiawi terutama berdampak terhadap air tanah dan air permukaan, selanjutnya terjadi perubahan secara fisik, yaitu morfologi dan topografi lahan, dan perubahan iklim mikro yang disebabkan oleh perubahan kecepatan angin, gangguan habitat biologi berupa flora dan fauna, serta penurunan produktivitas tanah dengan akibat menjadi tandus atau gundul.

Lahan pasca tambang apabila dapat dikelola dengan baik maka dimasa mendatang, lahan timbunan pasca penambangan batu bara merupakan salah satu sumberdaya yang berpotensi besar untuk mendukung pembangunan pertanian. Salah satu pemanfaatannya adalah menjadikan tanah lapisan atas bekas tambang batu bara sebagai alternatif media tanam pembibitan. Tanah lapisan atas bekas tambang batu bara memiliki kemasaman yang berlebih dibanding tanah pada umumnya dan memiliki 
konsentrasi hara makro $(\mathrm{N}, \mathrm{P}, \mathrm{K}$ dan $\mathrm{Mg}$ ) yang rendah, pada kondisi tanah seperti itu maka berbagai jenis tanaman budidaya tidak dapat tumbuh dengan baik.

Keberhasilan pertumbuhan ditentukan oleh faktor internal (genetik dan hormon) dan faktor eksternal (iklim dan kualitas tempat tumbuh). Sehingga perlu adanya percobaan penggunaan media tanah bekas lahan tambang batu bara yang diberi pembenah tanah yang diharapkan dapat berpengaruh baik di pembibitan maupun setelah dipindah ke lapangan. Pertambangan secara drastis mengubah sifat fisik dan kimia serta lingkungan biologis tanah.

Upaya yang harus dilakukan dalam peningkatan hara tanah di lahan bekas tambang batu bara adalah pemberian bahan pembenah tanah yang digunakan untuk mempercepat pemulihan kualitas tanah. Penggunaan pembenah tanah utamanya ditujukan untuk memperbaiki kualitas fisik, kimia, dan/atau biologi tanah, sehingga produktivitas tanah menjadi optimum. Tanah yang telah diberi pembenah tanah organik alami diharapkan dapat memberikan pangaruh baik bagi pertumbuhan dan perkembangan tanaman di pembibitan. Solid merupakan salah satu limbah padat dari hasil pengolahan minyak sawit kasar (Ruswendi, 2008).

Limbah decanter solid dari pabrik pengolahan kelapa sawit memiliki potensi yang cukup besar untuk dimanfaatkan sebagai bahan pembenah tanah organik Decanter solid merupakan limbah padat pabrik kelapa sawit (PKS). Solid berasal dari mesocarp atau serabut berondolan sawit yang telah mengalami pengolahan di PKS. Solid merupakan produk akhir berupa padatan dari proses pengolahan tandan buah segar di PKS yang memakai sistem decanter. Decanter digunakan untuk memisahkan fase cair (minyak dan air) dari fase padat sampai partikel-partikel terakhir. Decanter dapat mengeluarkan $90 \%$ semua padatan dari lumpur sawit dan $20 \%$ padatan terlarut dari minyak sawit. Aplikasinya pada tanaman kelapa sawit dapat meningkatkan kandungan fisik, kimia, biologi, tanah dan menurunkan kebutuhan pupuk anorganik (Pahan, 2008). Hasil analisis laboratorium menunjukkan bahwa solid memiliki kandungan bahan kering $81,65 \%$ yang di dalamnya terdapat protein kasar $12,63 \%$; serat kasar 9,98\%; lemak kasar 7,12\%; kalsium $0,03 \%$; fosfor $0,003 \%$; hemiselulosa 5,25\%; selulosa 26,35\%; dan energi $3454 \mathrm{kkal} / \mathrm{kg}$ (Utomo dan Widjaja, 2005).
Yuniza (2015) menyatakan bahwa unsur hara utama decanter solid kering antara lain Nitrogen (N) 1,47\%, Pospor (P) 0,17\%, Kalium (K) 0,99\%, Kalsium (Ca) 1.19\%, Magnesium (Mg) 0,24\% dan C-Organik 14,4\%. Limbah decanter solid dari pabrik pengolahan kelapa sawit memiliki potensi yang cukup besar untuk dimanfaatkan sebagai bahan pembenah tanah organik. Decanter solid mengandung unsur hara dan zat organik yang tinggi. Yuniza (2015) menyatakan bahwa unsur hara utama decanter solid kering antara lain Nitrogen (N) 1,47\%, Pospor (P) 0,17\%, Kalium (K) 0,99\%, Kalsium (Ca) 1,19\%, Magnesium (Mg) 0,24\% dan C-Organik 14,4\%.

Uji penanaman terhadap bibit kelapa sawit ini untuk mengetahui kelayakan tanah bekas lahan tambang batu bara dalam mendukung pertumbuhan tanaman dengan memberikan decanter solid ke dalam media tumbuh tanaman dan diharapkan penggunaan decanter solid dapat memperbaiki sifat fisik, kimia dan biologis serta menambah bahan organik di dalam tanah. Tujuan penelitian ini untuk mengetahui tanggap pertumbuhan bibit kelapa sawit dengan media tanah bekas lahan tambang batu bara yang diberi berbagai dosis decanter solid.

\section{METODE PENELITIAN}

Penelitian ini dilaksanakan di Pusat Pembibitan Tanaman Perkebunan Provinsi Jambi, Jl. Raya Lintas Jambi-Palembang Pal 16, Kecamatan Mestong, Kabupaten Muaro Jambi, Jambi. Penelitian ini dilaksanakan selama \pm 3 bulan yaitu dari bulan Maret s.d. Mei 2016.

Bahan yang digunakan adalah bibit kelapa sawit varietas (D x P) Tenera yang berasal dari Dinas Perkebunan Provinsi Jambi, tanah dari lahan bekas penambangan batu bara diperoleh dari PT. Agro Makmur Muara Jambi, pupuk NPK $\mathrm{Mg}+$ Kieserite, Polybag ukuran 35 x $40 \mathrm{~cm}$ dan decanter solid yang diperoleh dari Pabrik Minyak Kelapa Sawit PT. Inti Indosawit Subur Asian Agri Muara Bulian. Alat-alat yang digunakan dalam penelitian ini adalah cangkul, gembor, meteran, jangka sorong, label, timbangan analitik, ayakan, parang, gunting, sekop, kayu, pipa paralon, oven dan alat tulis.

Penelitian ini menggunakan rancangan acak kelompok (RAK) dengan perlakuan dosis (d) dengan 7 taraf yaitu: $\mathrm{d}_{0}$ : Tanah bekas lahan tambang batu bara sebagai kontrol (tanpa decanter solid), $\mathrm{d}_{1}: 100 \mathrm{~g} /$ polybag decanter solid, 
$\mathrm{d}_{2}: 200 \mathrm{~g} /$ polybag decanter solid, $\mathrm{d}_{3}: 300$ $\mathrm{g} /$ polybag decanter solid, $\mathrm{d}_{4}: 400 \mathrm{~g} /$ polybag decanter solid, $\mathrm{d}_{5}: 500 \mathrm{~g} /$ polybag decanter solid, $\mathrm{d}_{6}$ : 600 g/polybag decanter solid. Setiap perlakuan diulang 4 kali, sehingga terdapat 28 satuan percobaan. Setiap satuan percobaan terdiri dari 3 tanaman dan 3 tanaman sebagai tanaman sampel, dengan demikian jumlah seluruh tanaman adalah 84 tanaman. Data dianalisis dengan menggunakan analysis of variance dan untuk faktor perlakuan yang nyata akan dilanjutkan dengan uji lanjut Duncan Multiple Range Test (DMRT) pada $\alpha=5 \%$. Variabel pengamatan: luas daun $(\mathrm{cm})$, pertambahan tinggi tanaman $(\mathrm{cm})$, pertambahan diameter tanaman $(\mathrm{cm})$, luas daun total, laju pertumbuhan tanaman $(\mathrm{g} / \mathrm{tam} / \mathrm{hr})$ dan Index Mutu Bibit (IMB). Analisis tanah pada lahan bekas penambangan batu bara dan analisis decanter solid.

\section{HASIL DAN PEMBAHASAN}

\section{Pertambahan Tinggi Tanaman}

Data pengamatan dan hasil analisis ragam yang dilanjutkan dengan Uji DMRT (Tabel 1) menunjukkan bahwa pemberian perlakuan decanter solid memberikan pengaruh nyata terhadap pertambahan tinggi tanaman.

Tabel 1. Rata-rata Pertambahan Tinggi Bibit Kelapa Sawit tiap Perlakuan

\begin{tabular}{ccc}
\hline Perlakuan & Dosis Decanter Solid $(\mathrm{g})$ & Pertambahan Tinggi $(\mathrm{cm})$ \\
\hline $\mathrm{d}_{4}$ & $400 \mathrm{~g}$ & $17,17 \mathrm{a}$ \\
$\mathrm{d}_{3}$ & $300 \mathrm{~g}$ & $15,59 \mathrm{~b}$ \\
$\mathrm{~d}_{6}$ & $600 \mathrm{~g}$ & $15,27 \mathrm{bc}$ \\
$\mathrm{d}_{5}$ & $500 \mathrm{~g}$ & $13,83 \mathrm{c}$ \\
$\mathrm{d}_{2}$ & $200 \mathrm{~g}$ & $13,73 \mathrm{c}$ \\
$\mathrm{d}_{1}$ & $100 \mathrm{~g}$ & $12,67 \mathrm{c}$ \\
$\mathrm{d}_{0}$ & Tanpa Perlakuan & $8,04 \mathrm{~d}$ \\
\hline
\end{tabular}

Keterangan: Angka-angka yang diikuti oleh huruf yang berbeda menunjukkan berbeda nyata menurut Uji Duncan dengan taraf $\alpha=5 \%$

Pemberian decanter solid pada perlakuan $400 \mathrm{~g} /$ polybag menghasilkan pertambahan tinggi bibit kelapa sawit tertinggi yaitu $17,17 \mathrm{~cm}$ yang mana pemberian perlakuan tersebut berbeda nyata dengan perlakuan lainnya. Bibit kelapa sawit yang tanpa perlakuan menghasilkan pertambahan tinggi bibit terendah yaitu $8,04 \mathrm{~cm}$.

\section{Pertambahan Diameter Tanaman (mm)}

Data pengamatan dan hasil analisis ragam yang dilanjutkan dengan Uji DMRT menunjukkan (Tabel 2) bahwa pemberian perlakuan decanter solid memberikan pengaruh nyata terhadap pertambahan diameter bibit kelapa sawit.

Tabel 2. Rata-rata Pertambahan Diameter Bibit Kelapa Sawit tetiap Perlakuan.

\begin{tabular}{ccc}
\hline Perlakuan & Dosis Decanter Solid $(\mathrm{g})$ & Pertambahan Diameter $(\mathrm{mm})$ \\
\hline $\mathrm{d}_{4}$ & $400 \mathrm{~g}$ & $24,79 \mathrm{a}$ \\
$\mathrm{d}_{5}$ & $500 \mathrm{~g}$ & $24,63 \mathrm{a}$ \\
$\mathrm{d}_{6}$ & $600 \mathrm{~g}$ & $24,61 \mathrm{a}$ \\
$\mathrm{d}_{3}$ & $300 \mathrm{~g}$ & $24,60 \mathrm{a}$ \\
$\mathrm{d}_{2}$ & $200 \mathrm{~g}$ & $23,03 \mathrm{~b}$ \\
$\mathrm{~d}_{1}$ & $100 \mathrm{~g}$ & $22,10 \mathrm{c}$ \\
$\mathrm{d}_{0}$ & Tanpa Perlakuan & $17,22 \mathrm{~d}$ \\
\hline
\end{tabular}

Keterangan: Angka-angka yang diikuti oleh huruf yang berbeda menunjukkan berbeda nyata menurut Uji Duncan dengan taraf $\alpha=5 \%$

Tabel 2 memperlihatkan bahwa pemberian decanter solid pada perlakuan $400 \mathrm{~g} / \mathrm{polybag}$ menghasilkan pertambahan diameter bibit kelapa sawit terbesar yaitu $24,79 \mathrm{~mm}$ yang mana pemberian perlakuan tersebut berbeda nyata dengan perlakuan pemberian decanter solid $0 \mathrm{~g} /$ polybag, $100 \mathrm{~g} /$ polybag, $200 \mathrm{~g} /$ polybag. Bibit kelapa sawit yang tanpa perlakuan menghasilkan pertambahan diameter terkecil yaitu 17,22 $\mathrm{mm}$. 


\section{Luas Daun Total $\left(\mathrm{cm}^{2}\right)$}

Data pengamatan dan hasil analisis ragam yang dilanjutkan dengan Uji DMRT (Tabel 3) menunjukkan bahwa pemberian perlakuan decanter solid memberikan pengaruh nyata terhadap pertambahan luas daun bibit kelapa sawit.

Tabel 3. Rata-rata Pertambahan Luas Daun Total Bibit Kelapa Sawit.

\begin{tabular}{ccc}
\hline Perlakuan & Dosis Decanter Solid $(\mathrm{g})$ & Luas Daun Total $\left(\mathrm{cm}^{2}\right)$ \\
\hline $\mathrm{d}_{4}$ & $400 \mathrm{~g}$ & $902,93 \mathrm{a}$ \\
$\mathrm{d}_{5}$ & $500 \mathrm{~g}$ & $841,05 \mathrm{~b}$ \\
$\mathrm{~d}_{3}$ & $300 \mathrm{~g}$ & $836,48 \mathrm{~b}$ \\
$\mathrm{~d}_{6}$ & $600 \mathrm{~g}$ & $822,05 \mathrm{~b}$ \\
$\mathrm{~d}_{2}$ & $200 \mathrm{~g}$ & $748,92 \mathrm{c}$ \\
$\mathrm{d}_{1}$ & $100 \mathrm{~g}$ & $685,54 \mathrm{~d}$ \\
$\mathrm{~d}_{0}$ & Tanpa Perlakuan & $481,04 \mathrm{e}$ \\
\hline
\end{tabular}

Keterangan: Angka-angka yang diikuti oleh huruf yang berbeda menunjukkan berbeda nyata menurut Uji Duncan dengan taraf $\alpha=5 \%$

Pemberian decanter solid pada perlakuan $400 \mathrm{~g} /$ polybag menghasilkan pertambahan luas daun bibit kelapa sawit terluas yaitu $902,93 \mathrm{~cm}^{2}$. Pemberian perlakuan tersebut menunjukkan pengaruh berbeda nyata dengan perlakuan lainnya. Bibit kelapa sawit yang tanpa perlakuan menghasilkan pertambahan luas daun terendah yaitu $481,04 \mathrm{~cm}^{2}$.

\section{Rata-rata Laju Pertumbuhan Tanaman (g/tam/hr) pada akhir pengamatan.}

Data pengamatan dan hasil analisis ragam yang dilanjutkan dengan Uji DMRT (Tabel 4) menunjukkan bahwa pemberian perlakuan decanter solid memberikan pengaruh nyata terhadap Laju Pertumbuhan Tanaman (LPT) bibit kelapa sawit.

Tabel 4. Rata-rata Laju Pertumbuhan Tanaman (g/tam/hr)

\begin{tabular}{ccc}
\hline Perlakuan & Dosis Decanter Solid $(\mathrm{g})$ & LPT g/tam/hr \\
\hline $\mathrm{d}_{4}$ & $400 \mathrm{~g}$ & $0,60 \mathrm{a}$ \\
$\mathrm{d}_{5}$ & $500 \mathrm{~g}$ & $0,58 \mathrm{a}$ \\
$\mathrm{d}_{6}$ & $600 \mathrm{~g}$ & $0,51 \mathrm{~b}$ \\
$\mathrm{~d}_{3}$ & $300 \mathrm{~g}$ & $0,48 \mathrm{bc}$ \\
$\mathrm{d}_{2}$ & $200 \mathrm{~g}$ & $0,43 \mathrm{c}$ \\
$\mathrm{d}_{1}$ & $100 \mathrm{~g}$ & $0,36 \mathrm{c}$ \\
$\mathrm{d}_{0}$ & Tanpa Perlakuan & $0,28 \mathrm{~d}$ \\
\hline
\end{tabular}

Keterangan: Angka-angka yang diikuti oleh huruf yang berbeda menunjukkan berbeda nyata menurut Uji Duncan dengan taraf $\alpha=5 \%$

Pemberian decanter solid pada perlakuan $400 \mathrm{~g} /$ polybag menghasilkan LPT bibit kelapa sawit yaitu $0,60 \mathrm{~g} / \mathrm{tam} / \mathrm{hr}$ yang mana pemberian perlakuan tersebut berbeda tidak nyata dengan perlakuan pemberian $500 \mathrm{~g} /$ polybag dan berbeda nyata dengan perlakuan lainnya. Bibit kelapa sawit yang tanpa perlakuan menghasilkan LPT terendah yaitu $0,28 \mathrm{~g} / \mathrm{tam} / \mathrm{hr}$.

\section{Index Mutu Bibit (IMB)}

Data pengamatan dan hasil analisis ragam yang dilanjutkan dengan Uji DMRT (Tabel 5) menunjukkan bahwa pemberian perlakuan decanter solid memberikan pengaruh nyata terhadap IMB kelapa sawit.

Pemberian decanter solid pada perlakuan 500 g/polybag menghasilkan IMB bibit kelapa sawit yaitu 4,45 yang mana pemberian perlakuan tersebut berbeda tidak nyata dengan pemberian $400 \mathrm{~g} /$ polybag yaitu sebesar 4,29 dan berbeda nyata dengan perlakuan lainnya. Bibit kelapa sawit yang tanpa pemberian decanter solid menghasilkan IMB terendah yaitu 2,18. 
Tabel 5. Rata-rata Index Mutu Bibit (IMB) Kelapa Sawit tiap Perlakuan.

\begin{tabular}{ccc}
\hline Perlakuan & Dosis Decanter Solid $(\mathrm{g})$ & $\mathrm{IMB}$ \\
\hline $\mathrm{d}_{5}$ & $500 \mathrm{~g}$ & $4,45 \mathrm{a}$ \\
$\mathrm{d}_{4}$ & $400 \mathrm{~g}$ & $4,29 \mathrm{a}$ \\
$\mathrm{d}_{6}$ & $600 \mathrm{~g}$ & $3,84 \mathrm{~b}$ \\
$\mathrm{~d}_{3}$ & $300 \mathrm{~g}$ & $3,64 \mathrm{~b}$ \\
$\mathrm{~d}_{2}$ & $200 \mathrm{~g}$ & $3,27 \mathrm{c}$ \\
$\mathrm{d}_{1}$ & $100 \mathrm{~g}$ & $2,86 \mathrm{~d}$ \\
$\mathrm{~d}_{0}$ & Tanpa Perlakuan & $2,18 \mathrm{e}$ \\
\hline
\end{tabular}

Keterangan: Angka-angka yang diikuti oleh huruf yang berbeda menunjukkan berbeda nyata menurut Uji Duncan dengan taraf $\alpha=5 \%$

Unsur hara yang tersedia dalam jumlah rendah yang terdapat pada perlakuan tanpa diberi decanter solid (Tabel 6) menyebabkan tinggi tanaman, diameter batang, luas daun total, laju pertumbuhan dan IMB tanaman menjadi rendah.
Salah satu langkah perbaikan hara yang dapat dilakukan untuk meningkatkan efisiensi serapan unsur hara bagi tanaman adalah pemberian pembenah tanah dalam hal ini adalah limbah kelapa sawit yaitu decanter solid.

Tabel 6. Analisis Tanah pada Lapisan Tanah Atas Bekas Penambangan Batu Bara

\begin{tabular}{ccccc}
\hline $\mathrm{pH}$ & $\mathrm{C}(\%)$ & $\mathrm{N}(\%)$ & $\mathrm{P}$ tersedia $(\mathrm{ppm})$ & $\mathrm{K}_{2} \mathrm{O}(\%)$ \\
\hline 4,5 & - & 0,080 & 0,10 & 0,092 \\
\hline
\end{tabular}

Pada Tabel 1, 2 dan 3 memperlihatkan bahwa pemberian decanter solid pada perlakuan $400 \mathrm{~g} /$ polybag menghasilkan pertambahan tinggi dan diameter bibit kelapa sawit yang terbaik. Rendahnya unsur $\mathrm{N}$ dan $\mathrm{P}$ sebagai unsur hara makro dimedia bibit merupakan faktor pembatas yang mempengaruhi proses pertumbuhan tanaman. Dari analisa decanter solid terlihat bahwa decanter solid dapat memberikan kontribusi unsur hara dan dapat meningkatkan pertumbuhan tanaman.

Decanter solid menyediakan unsur hara $\mathrm{N}$ dan $\mathrm{P}$ yang cukup (Tabel 7) dimana unsur hara $\mathrm{N}$ dan
$\mathrm{P}$ pada media bibit dapat membantu proses pembelahan dan pembesaran sel yang menyebabkan daun muda lebih cepat mencapai bentuk sempurna. Hal ini sesuai dengan pendapat Lakitan (2001), bahwa ketersediaan unsur $\mathrm{N}$ dan $\mathrm{P}$ akan mempengaruhi daun dalam hal bentuk dan jumlah. Unsur hara yang paling berpengaruh terhadap pertumbuhan dan perkembangan daun adalah nitrogen. Bila tanaman kekurangan nitrogen, maka sintesis klorofil, protein dan pembentukan sel baru akan terhambat. Akibatnya tanaman tidak mampu membentuk organ-organ seperti daun.

Tabel 7. Analisis Kandungan Hara Decenter Solid

\begin{tabular}{cccccc}
\hline \multirow{2}{*}{$\mathrm{pH}$} & $\mathrm{C}(\%)$ & \multicolumn{3}{c}{ Total $(\%)$} & \multirow{2}{*}{ Kadar Air (\%) } \\
\cline { 3 - 5 } & 7,80 & $\mathrm{~N}$ & $\mathrm{P}_{2} \mathrm{O}_{5}$ & $\mathrm{~K}_{2} \mathrm{O}$ & \\
\hline 5,5 & 1,56 & 0,33 & 1,04 & 16,20 \\
\hline
\end{tabular}

Menurut Vitta (2012) untuk mempercepat perkembangan perakaran, maka unsur hara harus dapat memacu proses pembelahan sel dan metabolisme tanaman sehingga mendorong laju pertumbuhan tanaman diantaranya perkembangan diameter batang. Unsur hara yang tersedia dalam media bibit yang telah diberi dicenter solid dapat memperbaiki struktur tanah sehingga pertumbuhan akar menjadi baik, penyerapan air oleh tanaman menjadi meningkat, sehingga mampu mendukung pertumbuhan tanaman dan peningkatan luas daun.

Tinggi dan diameter merupakan dua syarat khusus yang harus dipenuhi dalam penentuan mutu bibit. Pentingnya persyaratan pengukuran terhadap diameter pangkal bibit dikarenakan diameter batang yang besar persen hidupnya lebih tinggi dan pertumbuhannya lebih cepat sesuai untuk areal terbuka dan lahan kritis (Danu et al., 2006). Dengan diameter yang besar diharapkan akan tumbuh dan menghasilkan pohon dengan 
diameter yang besar sehingga produksi yang dihasilkan juga tinggi.

Pertumbuhan diameter suatu bibit dipengaruhi unsur kalium yang tersedia, dalam decanter solid unsur hara kalium cukup tinggi (Tabel 7). Tersedianya unsur hara kalium maka pembentukan karbohidrat akan berjalan dengan baik dan translokasi pati ke bonggol bibit akan semakin lancar, sehingga akan terbentuk bonggol bibit yang baik. Leiwakabessy (1998) menyatakan unsur kalium sangat berperan dalam meningkatkan diameter bonggol tanaman, khususnya sebagai jaringan yang berhubungan antara akar dan daun pada proses transpirasi. Pernyataan ini diperkuat oleh pendapat Ardiana et al. (2016) bahwa batang merupakan daerah akumulasi pertumbuhan tanaman khususnya pada tanaman yang lebih muda sehingga dengan adanya unsur hara dapat mendorong pertumbuhan vegetatif tanaman diantaranya pembentukan klorofil pada daun sehingga akan memacu laju fotosintesis. Semakin laju fotosintesis maka fotosintat yang dihasilkan akan memberikan ukuran pertambahan diameter batang yang besar.

Laju pertumbuhan tanaman dan IMB hasilnya lebih tinggi pada media bibit yang diberi decanter solid dibandingkan perlakuan tanpa diberi decanter solid. Hal ini menunjukkan bahwa tanah lapisan atas bekas tambang batu bara yang diberi pembenah tanah decanter solid dapat meningkatkan laju pertumbuhan tanaman serta meningkatkan IMB, sedangkan pada media bibit tanpa diberi decanter solid pertumbuhannya terhambat. Hal ini memperlihatkan bahwa lapisan tanah atas bekas tambang batu bara (Tabel 6) apabila akan dijadikan media bibit harus diberi pupuk atau pembenah tanah terlebih dahulu.

Unsur mutlak yang dibutuhkan tanaman adalah unsur nitrogen. Unsur ini dibutuhkan untuk memproduksi protein dan bahan-bahan penting lainnya dalam pembentukan sel-sel baru serta berperan dalam pembentukan klorofil. Unsur hara yang terdapat pada limbah solid dapat memacu proses pembelahan sel, sehingga laju pertumbuhan tanaman dapat bekerja dengan baik. Hal ini didukung dari hasil penelitian Nasution et al. (2014) bahwa pemberian berbagai perbandingan media tanam decanter solid dan tandan kosong kelapa sawit dalam single stage tanaman kelapa sawit memberikan pengaruh nyata terhadap tinggi tanaman, diameter batang, jumlah klorofil daun, bobot kering akar, bobot kering tajuk, rasio tajuk akar bibit kelapa sawit, volume akar bibit kelapa sawit.

Bobot kering tanaman (akar dan tajuk) menunjukkan tingkat efesiensi metabolisme dari tanaman tersebut. Akumulasi bahan kering digunakan sebagai indikator ukuran pertumbuhan. Akumulasi bahan kering mencerminkan kemampuan tanaman dalam mengikat energi dari cahaya matahari melalui proses fotosintesis, serta interaksi dengan faktor lingkungan lainnya (Fried dan Hademenos, 2000). Bobot kering total tertinggi diperoleh pada pemberian decanter solid $400 \mathrm{~g} /$ polybag. Hal ini menunjukkan bahwa laju translokasi asimilat pada media tanam campuran ini lebih tinggi dibandingkan media tanam lainnya. Biomassa tanaman mengindikasikan banyak senyawa kimia yang terkandung dalam tanaman. Semakin tinggi biomassa maka senyawa kimia yang terkandung didalamnya lebih banyak sehingga meningkatkan berat kering tanaman.

\section{KESIMPULAN}

Secara umum pemberian decanter solid terhadap pertumbuhan bibit kelapa sawit dengan media lapisan tanah atas bekas lahan tambang batu bara memberikan pertumbuhan yang lebih baik terhadap tinggi, diameter, jumlah daun, serta luas daun dibandingkan dengan bibit kelapa sawit yang tanpa diberi decanter solid. Peningkatan pertumbuhan bibit kelapa sawit yang terbaik adalah pada pemberian decanter solid dengan dosis $400 \mathrm{~g} /$ polybag.

\section{DAFTAR PUSTAKA}

Ardiana, R., Anom, A., \& Armaini. 2016. Aplikasi Solid Pada Medium Bibit Kelapa Sawit (Elaeis guineensis Jacq.) di Main Nursery. Jom Faperta. 3(1).

Danu, Rohadi, D., \& Nurhasybi. 2006. Teknologi dan Standarisasi Benih dan Bibit dalam Menunjang Keberhasilan Gerhan. Prosiding Seminar Hasil-hasil Penelitian. Pusat Penelitian dan Pengembangan Hutan dan Konservasi Alam. Bogor (ID). Hal. 63-76.

Fried, G.H., \& Hademenos, G.J. 2000. Scahum's Outlines of Theory and Problem of Biology $2^{\text {nd }}$ edition. The McGraw-Hall Companies. 
Kumar, A., \& Pandey, A. 2013. Evaluating Impact of Coal Mining Activity on Landuse/Landcover Using Temporal Satellite Images in South Karanpura Coalfields and Environs, Jharkhand State, India. International Journal of Advanced Remote Sensing And GIS. 2(1), 183-197. Retrieved from http://technical.cloudjournals.com/index.php/IJARSG/article/view/ Tech-110

Pribadi, A. 2012. Reklamasi lahan bekas tambang batu bara. Fakultas Pertanian. Universitas Pembangunan Nasional Veteran. Jogyakarta. agungagroteknology.blogspot.com. diakses tanggal 7 Juni 2014

Lakitan, B. 2001. Dasar-Dasar Fisiologi Tumbuhan. Jakarta: Rajawali Pers.

Leiwakabessy, F.M., \& Sutandi, A. 1998. Diktat Kuliah Pupuk dan Pemupukan. Jurusan Tanah. Fakultas Pertanian IPB. Bogor.

Lubis, A.S. 2014. Pelaksanaan Reklamasi Lahan Bekas Tambang Batu bara. Dinas ESDM Provinsi Jambi.

Nasution S.H., Chairani, H., \& Jasmani, G. 2014. Pertumbuhan Bibit Kelapa Sawit (Elaeis guineensis Jacq.) pada berbagai Perbandingan Media Tanam Solid Decanter dan Tandan Kosong Kelapa Sawit Pada Sistem Single Stage. Jurnal Online Agroekoteknologi. 2(2), 691-701.
Pahan, I. 2008. Panduan Lengkap Kelapa Sawit: Manajemen Agribisnis dari Hulu hingga Hilir. Jakarta: Penebar Swadaya.

Pusat Penelitian Kelapa Sawit. 2010. Pembibitan Kelapa Sawit. Pusat Penelitian Kelapa Sawit. Medan.

Ruswendi, W.A., Wulandari, \& Gunawan. 2006. Pengaruh Penggunaan Pakan Solid dan Pelepah Kelapa Sawit Terhadap Pertambahan Bobot Badan Sapi Potong. Prosiding Lokakarya Hasil Pengkajian Tehnologi Pertanian. BBP2TP - Badan Litbang Pertanian. Bogor. Pp. 105-108.

Utomo, N.U., \& Widjaja. 2005. Limbah Padat Pengolahan Minyak Sawit Sebagai Sumber Nutrisi Ternak Ruminansia. Balai Pengkajian Teknologi Pertanian Kalimantan Tengah http://www.pustakadeptan.go.id/publikasi/p32 31044.pdf. Diakses pada tanggal 24 Mei 2015.

Vitta, P.M. 2012. Analisis Kandungan Hara N dan P Serta Klorofil Tebu Transgenik IPB 1 yang Ditanam Dikebun Percoban PG DJatitirto, Jawa Timur. Bogor: Fakultas Pertanian IPB.

Yuniza, Y. 2015. Pengaruh Pemberian Kompos Decanter Solid dalam Media Tanam terhadap Pertumbuhan Bibit Kelapa Sawit (Elaeis guineensis Jacq.) di Pembibitan Utama. Program Studi Agroekoteknologi Fakultas Pertanian Universitas Jambi. Jambi. 